OPEN ACCESS

Edited by:

Eric Wolanski,

James Cook University, Australia

Reviewed by:

Andrew Baird,

James Cook University, Australia Hajime Kayanne,

The University of Tokyo, Japan

${ }^{*}$ Correspondence:

Robert H. Richmond

richmond@hawaii.edu

Specialty section This article was submitted to Marine Ecosystem Ecology, a section of the journal Frontiers in Marine Science

Received: 28 March 2018 Accepted: 12 June 2018

Published: 02 July 2018

Citation:

Richmond RH, Tisthammer $\mathrm{KH}$ and Spies NP (2018) The Effects of Anthropogenic Stressors on Reproduction and Recruitment of

Corals and Reef Organisms.

Front. Mar. Sci. 5:226.

doi: 10.3389/fmars.2018.00226

\section{The Effects of Anthropogenic Stressors on Reproduction and Recruitment of Corals and Reef Organisms}

\author{
Robert H. Richmond ${ }^{*}$, Kaho H. Tisthammer and Narrissa P. Spies \\ Kewalo Marine Laboratory, University of Hawaii at Manoa, Honolulu, HI, United States
}

The persistence of populations of marine organisms depends on the success of the dual processes of reproduction and recruitment. The production of offspring alone is inconsequential unless larvae and propagules can recruit, which often entails a period of development and distribution in the water column and subsequent selection of appropriate habitats. For fish, this may mean drifting in currents before responding to particular habitat cues. For corals and other benthic invertebrates, larvae must undergo site selection, settlement and metamorphosis into the juvenile form, and survivorship is directly linked to site choice and environmental conditions. Both biotic and abiotic factors affect population replenishment success, and hence, anthropogenic influences such as pollution, sedimentation and climate change can negatively affect critical processes such as reproductive synchronization in spawning species, successful embryological development, appropriate site selection, settlement, metamorphosis and in the case of reef building corals, acquisition of the required zooxanthellae partner. Effective management practices are essential for ensuring the persistence of populations of coral reef organisms of economic, cultural and ecological value.

Keywords: corals, planulae, larval development, larval recruitment, pollution and global change, climate change impacts, metamorphic induction, anthropogenic stressors

\section{REPRODUCTION AND RECRUITMENT}

Reproduction is the process by which new individuals are formed from parental stock, and can occur through asexual or sexual means. In corals, the most common type of asexual reproduction is via fragmentation, and often involves physical separation of a portion of the tissue-covered skeleton. This can occur as a result of fish feeding on associated crabs, shrimp, bivalves or barnacles, and the driver of recruitment "behavior" is gravity, that is, the fragment sinks, settles, attaches and hopefully survives. Other means of asexual reproduction can occur via tissue sloughing or polyp bail out, and the resulting ciliated tissue bits can disperse over greater distances and exhibit selective settlement behavior (Sammarco, 1982). Larvae can also be produced via parthenogenesis, and while genetically identical to the parent colony, exhibit classic larval behaviors. Sexual reproduction involves the fusion of sperm and egg (gametes) produced by the male and female of the species respectively. Sexual reproduction results in two opportunities for increasing genetic variability: one through the contributions of two different parents to the offspring and another through the "crossing over" among chromosomes that occurs during the prophase one stage of meiosis, the reduction division that makes haploid (1n) gametes that 
fuse to become a diploid (2n) organism. No matter how the progeny are formed, they do not contribute to the population unless they successfully recruit, and that is where behavior comes in.

The persistence of populations depends on the success of both reproduction and recruitment processes. With a focus on the importance of larval behavior for successful recruitment, the following discussion will center on sexual reproduction as the primary means of producing this critical life history stage for the perpetuation of coral reefs and related ecosystems. There are six chemically mediated steps involved in the replenishment of reef populations: gamete development within mature coral colonies, synchronization of gamete release, successful fertilization of eggs by sperm, complete embryological development to the competent larval stage, settlement and metamorphic induction, and acquisition of symbiotic zooxanthellae in recruits that do not have them vertically transmitted by the parent colony (Richmond, 2014; Figure 1). These key processes are affected by both density dependent and density independent factors.

As with all sessile and benthic organisms, for reproductive events to be successful in the production of viable larvae, a critical density of parental stock is required. As the distance between individuals and colonies of the same species increases, the incidence of appropriate egg-sperm interactions decreases, with reduced levels of fertilization and larval production. This is called the Allee Effect, and is well known within marine organisms (Gascoigne and Lipcius, 2004). Population density is a function of environmental conditions, stressors and disturbance.

Water and bottom quality are essential parameters that affect the health of coral reefs and other marine ecosystems. Reduced water quality can stress adult populations, inhibiting gametogenesis and reducing chemical signaling between conspecifics that helps with the synchronization of spawning, the viability of gametes, fertilization success and the ability of embryos to develop into viable planula larvae. As gametes (egg and sperm) are among the most sensitive life history stages to environmental parameters, terrigenous runoff is a

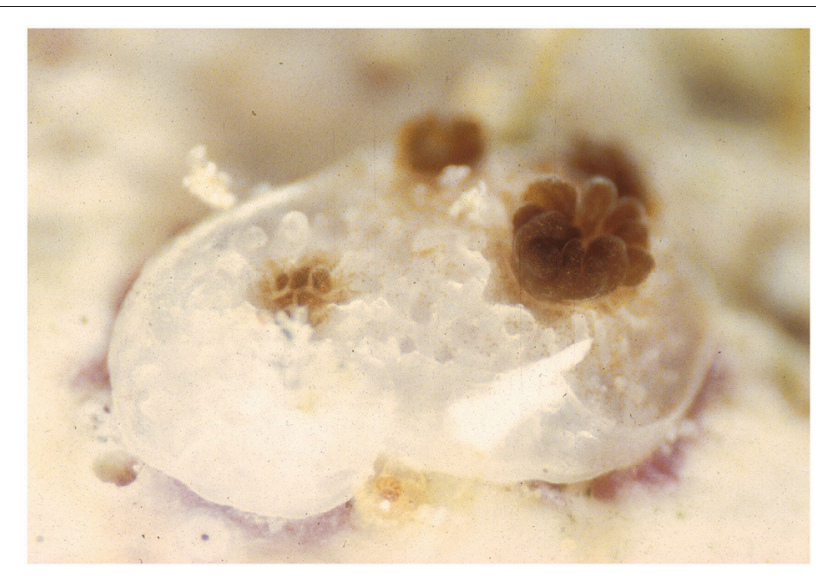

FIGURE 1 | Recent coral recruit exhibiting colony growth through extra-tentacular budding and the acquisition of symbiotic zooxanthellae from the ambient environment. serious problem that impacts reproduction of marine organisms (Richmond, 1993). Bottom quality affects recruitment success in corals and many other benthic invertebrates. Sediment cover prevents larvae from sensing key settlement cues, both chemical and textural, from preferred substrata such as crustose coralline algae. Larval metamorphic induction may be prevented by sediment and algal cover through substrate instability, the alteration of the benthic microbiome, and the alteration of bottom chemistry. In addition to the local stressors mentioned above, increased temperatures and ocean acidification tied to global climate change are factors that also affect reproduction and recruitment in a broad range of marine organisms. These anthropogenic issues will be discussed below.

\section{LARVAL COMPETENCY}

The competency period of larvae, the time during which they can successfully disperse, settle and metamorphose, is an important determinant of connectivity among sites and populations. The longer the competency period, the greater the distributional range of a species, and broader distributions translate into enhanced survival of species exposed to local and global level stressors with the associated threat of local extinction. The competency period of larvae is tied to nutritional mode and energy availability. Planktotrophic larvae actively feed, and often have specific structures that aid in food capture. They have a delay before they can recruit, the pre-competency period, during which time they undergo additional development and often, morphological changes. Lecithotrophic larvae survive primarily on stored energy reserves, such as lipids provided in the eggs. The term mixotrophic refers to larvae that use a combination of stored energy reserves and planktonic feeding, which can include absorption of dissolved nutrients, and in the case of corals, translocated metabolites from symbiotic zooxanthallae.

While in the plankton, larvae are not limited to drifting at the mercy of currents, but can exert a degree of control through vertical and horizontal swimming behaviors. Such movement can change the water parcels in which the larvae are contained and hence, the direction and speed of travel, ambient temperature that affects larval development and metabolic rates, and light levels including photosynthetically active radiation (PAR) and UV exposure. An extreme example is for larvae that get entrained in water parcels affected by the Kelvin Wave associated with the onset of El Nino conditions. Such larvae can be transported over hundreds to thousands of $\mathrm{km}$ over a period of weeks to months (Richmond, 1990). Downward vertical movement of larvae can also affect entrainment of larvae in bottom currents and eddies that enhances recruitment on coral reefs and other benthic habitats. Recent research has demonstrated that larval swimming behavior can be influenced by a number of parameters including light, gradients of salinity and temperature, as well as by auditory and chemical cues. Both fish and invertebrate larvae have been documented to respond to reef sounds that aid in the recruitment of larvae to reefs, and chemical cues can influence larval swimming and settlement behavior (Vermeij et al., 2010). While both auditory and chemical cues can attract larvae, the 
distance over which some, including coral planulae, can swim is limited (Figueiredo et al., 2014; Hata et al., 2017).

Fish larvae usually have an initial distribution pattern tied to currents, but after a degree of development and spinal hardening, can begin to exhibit directional swimming. Coral reef fish, as opposed to pelagic species, need to find specific habitats in order to recruit, grow and eventually reproduce, hence, cueing behavior is of paramount importance. Specific cues include sounds and smells. Waves impacting reefs and other barriers send sounds over relatively long distances. Interestingly, these reflections and refractions of wave energy are also used by traditional navigators in the Pacific Islands to identify the location of landmasses and submerged features. Over shorter distances, the sounds of crabs, snapping shrimp and fish can help larvae navigate toward healthy reefs. Dead reefs and reefs in decline may provide fewer cues to which larvae can respond (Dixson et al., 2014). The natural chemistry of reefs, tied to everything from coral mucus, algae and bacteria, also provides signals to larvae, which possess chemoreceptors. Toxicants that block these chemical signals or the larval receptors, act to impede recruitment (Peters et al., 1997).

Coral planula larvae do not randomly settle and metamorphose, but rather, select their recruitment sites (Golbuu and Richmond, 2007). Bacteria have been specifically identified as important cues for coral larval recruitment to specific substrata. Coral planulae have been found to also respond to specific crustose coralline algae (CCA), likely due to associated polysacchides and glycoglycerolipids (Tebben et al., 2015; Figure 2).

Coral larvae from brooding species and some spawning species (e.g., Montipora) possess symbiotic zooxanthellae that are vertically transmitted from the parent colony. These algal cells provide additional energetic input to the larvae and can extend the competency period (Richmond, 1987). While the period during which these larvae can successfully settle and metamorphose can extend from weeks to months, translating into the potential for long-distance dispersal, studies have shown that most larvae travel over short distances and many reefs are self-seeding (Sammarco et al., 1989; Jones et al., 1999; Figueiredo et al., 2013). This is due to a combination of abiotic factors (currents and associated eddies) and larval behavior, including cueing to the biotic factors of natal reefs, identified above.

Water quality remains a key concern during the planktonic phase of larvae throughout the competency period. Substratum quality is also important for settlement and metamorphosis to occur. The implications are that efforts to protect bottom and water quality in and around coral reef ecosystems are of critical importance to maintaining reef populations by supporting successful reproduction and larval recruitment.

\section{THE EFFECTS OF STRESSORS ON CORAL REPRODUCTION AND RECRUITMENT}

\section{Water Quality}

The world's nearshore marine habitats are being increasingly exposed to a variety of anthropogenic stressors, such as sedimentation, eutrophication, pollution, and overfishing (Morgan et al., 2016), all of which have a profound impact on reproduction, recruitment and survival of larvae. As mentioned above, early life stages of many marine organisms are more sensitive to pollutants than adult stages (Reichelt-Brushett and Harrison, 1999), due in part to the important role that chemical cues play in substrate selection and metamorphosis of larvae in many marine organisms (Hadfield and Paul, 2001; Freckelton et al., 2017). For example, many species of coral larvae use chemical cues to settle on a substratum where specific coralline algae and/or their associated bacteria are present (Golbuu and Richmond, 2007; Vermeij et al., 2008; Tebben et al., 2015). Recently, a single bacterial metabolite, tetrabromopyrrole, was shown to induce metamorphosis in certain coral species, occurring even without attachment to a substratum (Tebben et al., 2011; Sneed et al., 2014). Chemical pollutants, therefore, affect key life stages and behaviors of corals and other marine organisms by interfering with their chemosensory functions.
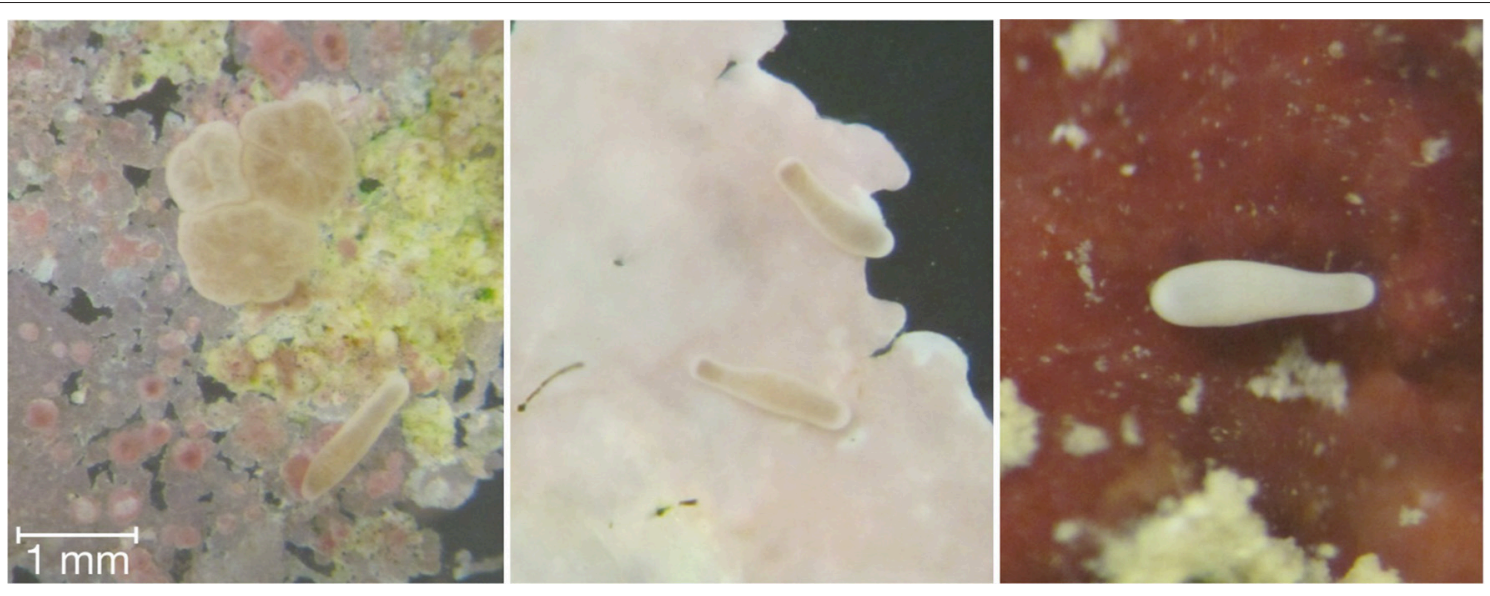

FIGURE 2 | Coral planulae undergoing settlement and metamorphosis (panel 1) following exploration of the substrata (panels 2 and 3 ) and encountering the proper chemical/biotic cues. 

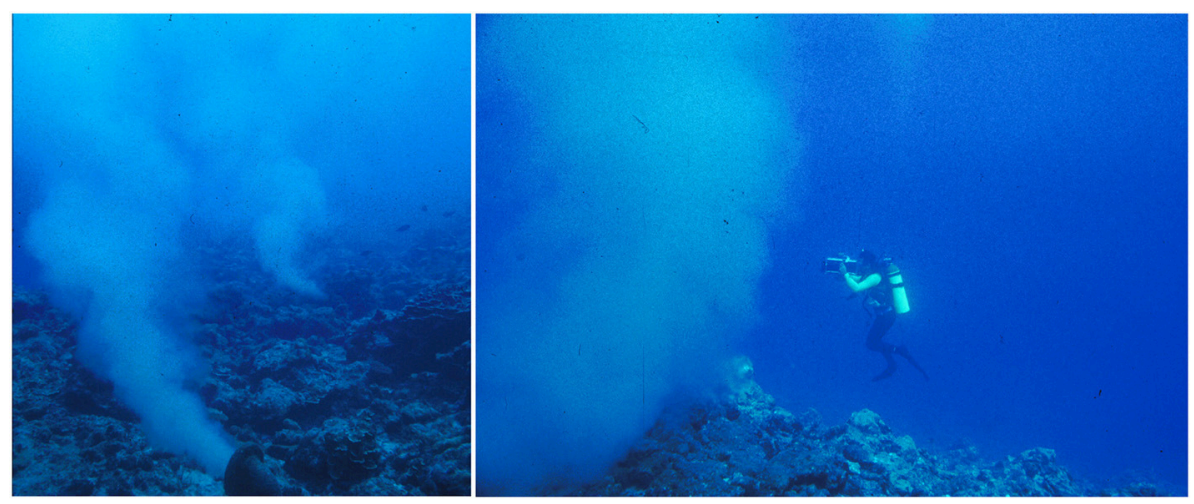

FIGURE 3 | Sewage discharges along a reef on Guam, resulting in decreased recruitment of coral larvae. The freshwater effluent rises $100 \%$ of the time and bathes the adjacent shallow water reef area when there is an onshore wind. The chemical content includes personal care products, heavy metals, pesticides,

pharmaceuticals, hydrocarbons and even estrogenic compounds from un-metabolized birth control pills.

A variety of chemical agents are introduced into our coastal waters via coastal development, terrestrial runoff, sewage outfalls and toxic antifouling paints from ships (Figure 3). Many studies have shown the negative effects of these agents on coral larvae and their behaviors (Woods et al., 2016). For example, increased heavy metal concentrations reduce fertilization rates, larval survival, settlement success, metamorphosis, and growth rates of reef-building corals. Copper $(\mathrm{Cu})$ is shown to affect all of the above stages in coral larvae at relatively low concentrations (Reichelt-Brushett and Harrison, 1999, 2000; Victor and Richmond, 2005; Negri and Hoogenboom, 2011). In fact, $\mathrm{Cu}$ inhibits the metamorphosis of coral larvae at the lowest concentration of any metals tested so far (Reichelt-Brushett and Harrison, 1999). Exposure to iron (Fe) induced oxidative stress responses and DNA damage in coral larvae (Vijayavel et al., 2012), affecting their metabolic functions and behaviors. Exposure of coral larvae to mercury, cadmium and zinc showed neutral or mixed results (Heyward, 1988; Reichelt-Brushett and Harrison, 1999, 2005; Farina et al., 2008), suggesting interspecific differences in sensitivity to these metals.

The effects of organic compounds such as anti-fouling agents, hydrocarbons, and pesticides have been increasingly studied in marine organisms, including their impacts on reproductive and larval recruitment success. Tributylin (TBT) and Irgarol 1051 are active compounds of anti-fouling paints, and are reported to inhibit larval settlement and/or metamorphosis (Negri et al., 2002; Inoue, 2004; Negri and Marshall, 2009; Knutson et al., 2011). Since the banning of applying paints with TBT in 2003 by the International Maritime Organization, the use of the algaecide Irgarol in marine paints has increased dramatically. However, even relatively small concentrations of Irgarol can inhibit coral larval settlement (Knutson et al., 2011), which suggests that the Irgarol use may need to be reevaluated. Hydrocarbons, such as crude oil, dispersed oil, oil dispersant, and benzo[a]pyrene, are all reported to negatively affect fertilization, metamorphosis, and settlement of coral larvae (Epstein et al., 2000; Lane and Harrison, 2000; Negri and Heyward, 2000; Goodbody-Gringley et al., 2013). Oil dispersants and dispersed oil appear to have more negative effects than crude oil itself (i.e., water soluble fractions); morphological deformations and loss of normal swimming behavior of coral larvae were observed with exposure to dispersants and dispersed oil (Epstein et al., 2000).

Corals are holobionts, harboring endosymbiotic algae, zooxanthellae (Symbiodinium spp.), in their tissues. These algal symbionts provide the majority of the coral's energy needs through photosynthesis. Increased detection of herbicides and insecticides in marine environments has raised serious concerns regarding their impacts on coastal coral reef ecosystems (Markey et al., 2007; van Dam et al., 2011), since some herbicides used in agriculture and antifouling paints, such as diuron and atrazine, are photosystem II (PSII) inhibitors that directly affect zooxanthellae's functions (Owen et al., 2002; Jones et al., 2003; Jones, 2004, 2005). Our understanding about how these herbicides and insecticides affect coral hosts is still limited. The effects of pesticides found in coastal waters, on coral reproduction and physiology, are of high concern to resource managers. Our results from laboratory exposure experiments showed that the tested herbicides and insecticides had negative effects on at least one or more of coral life stages. For example, Roundup ${ }^{\circledR}$ (Monsanto Company) significantly reduced fertilization and settlement rates in corals at very low concentrations $(0.0069 \mathrm{ppm})$, and caused damage to eggs at a relatively low concentration ( $>0.35 \mathrm{ppm}$ ) (Diu, 2016). Another emerging pollutant gaining attention in the marine environment is the active ingredient in some sunscreens, oxybenzone. Increased mortality, deformation, and DNA damage, as well as reductions in photosynthetic efficiency were observed in coral larvae exposed to oxybenzone (Downs et al., 2016). These observations raise concerns about the environmental safety of other personal care products that enter into coastal waters and the open ocean.

\section{Bottom Quality}

Water and substratum quality are critical components affecting both reproduction and recruitment of marine organisms. In order for successful population replenishment to occur, 
consideration must be given to the source areas, the conduits of connectivity and the recipient sites. For example, larvae formed at one site will be physiologically compromised or killed if transported across an area affected by polluted and sediment-laden watershed discharges (Victor et al., 2006). Even a drop in salinity will affect survivorship of many types of larvae, including corals and echinoderms (Richmond and Jokiel, 1984). Contaminated recipient sites and those with accumulated sediment will also be inhospitable to benthic invertebrate and fish larvae from clean source sites, as such degradation will affect critical chemically cueing.

Sedimentation affects the success of reproduction and recruitment several different ways. During spawning events, sediment, particularly the finer clay-size particles, can adhere to eggs, causing them to sink rather than float to the ocean's surface, where fertilization often occurs. Sediment is a major carrier of toxicants from land to the sea, where the change in chemistry can cause contaminant release (Figure 4). Such pollutants include petroleum products (polycyclic aromatic hydrocarbons-PAH's), pesticides (both insecticides and herbicides), personal care products and heavy metals. Sediment particles often serve as nuclei that aggregate organic material, including mucus and phytoplankton, which harbor bacteria, and when this material sinks to the bottom, it increases biological oxygen demand (BOD), dropping both oxygen levels and $\mathrm{pH}$ at the sedimentwater interface (Wolanski et al., 2003). This effect can negatively impact the survivorship and growth of larval recruits. Finally, sediment blocks key metamorphic inducers needed by many types of larvae, and most benthic epifaunal larvae cannot recruit to such unstable substrata.

Sediments impact reproductive, larval behavior and recruitment success. In additional to the chemical effects listed above, sediment has physical effects that in turn, affect the physiology of organisms. For organisms dependent upon photosynthesis for energy, metabolism, growth and reproductive allocation, the shading effects of sediment block photosynthetically active radiation (PAR) that is essential to running the light-mediated chemical reactions. Turbidity, expressed as a weight per unit volume of water (e.g., $\mathrm{mg} / \mathrm{l}$ ), is especially problematic for photosynthesis. Sedimentation deposition rate, a weight per unit area over a given time period (e.g., g/ $\mathrm{m}^{2} /$ day) impacts both photosynthesis and energetics, due to the cost of shedding particles. Sediment can be re-suspended numerous times, so even without the addition of new materials from land-based sources, waves can result in additional impacts through reintroducing particles into the water column.

\section{Temperature}

Coral larvae remain viable and competent within the ambient temperature range of the parent colonies (Woolsey et al., 2015). As with adult colonies, deviations of a few degrees above or below the norm can have deleterious effects, such as reducing competency or inducing mortality. The expected increase in tropical and subtropical seawater temperatures of $2-4^{\circ} \mathrm{C}$ due to climate change, has major implications for coral larval survival, development, dispersal, and settlement (IPCC, 2007). Temperature is tied to larval development, and alterations

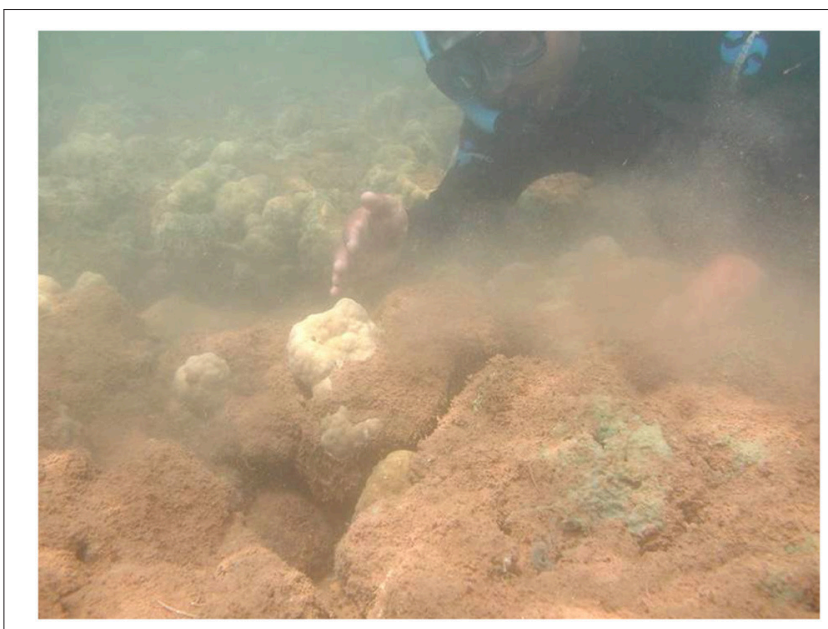

FIGURE 4 | Sediment covering the reef surface blocks metamorphic inducers and prevents larval recruitment.

in the ambient rearing temperature can have drastic effects. Abnormalities in embryogenisis of the spawning coral Acropora millepora were seen at $32^{\circ} \mathrm{C}\left(4^{\circ} \mathrm{C}\right.$ above ambient temperature where gametes where collected), as well as decreased fertilization rates, with no fertilization occurring at $34^{\circ} \mathrm{C}$ (Negri et al., 2007). A temperature increase reduced pre-competency periods by as much as an entire day in some coral species, which can affect the dispersal range for coral species, as well as impede the ability for devastated coral reefs to recruit new individuals and recover following bleaching events (Heyward and Negri, 2010). Model predictions suggest that increasing temperatures will serve to increase local retention of coral planulae due to reduced competency periods, and reduce connectivity among reefs separated by greater distances (Figueiredo et al., 2014). The implications are positive for locally targeted conservation efforts but raise additional concerns for reefs and populations dependent on external larval supplies for recovery and enhancing genotypic diversity.

Elevated temperature effects on coral planulae can have regional implications for population replenishment as well as global ones, as higher latitude larvae tend to develop more slowly than their tropical counterparts. An increase of even a single degree $\left({ }^{\circ} \mathrm{C}\right)$ above the normal range can increase the metabolic expenditure of stored energy, increasing premature metamorphosis and reducing recruitment success in addition to causing outright mortality (Edmunds et al., 2001; Graham et al., 2017). In aposymbiotic larvae from Diploria strigosa, a $2^{\circ} \mathrm{C}$ rise in temperature from an ambient $28^{\circ} \mathrm{C}$ seawater temp caused $50 \%$ mortality, and an increase to $31^{\circ} \mathrm{C}$ caused $70 \%$ mortality (Bassim and Sammarco, 2003).

As mentioned, coral larvae respond to different chemical and biological cues, and must have an appropriate settlement substrate for successful settlement and metamorphosis to occur. Temperature experiments elevating seawater to $32^{\circ} \mathrm{C}$ for a period of a week have been able to bleach CCA, also resulting in a shift in its microbial community (Webster et al., 2010). Acropora 
millepora larval settlement and metamorphosis was reduced by $50 \%$ when these planulae were exposed to bleached CCA compared to healthy CCA from ambient seawater conditions. While a microbial shift can occur by altering the chemical compounds released by CCA, it's also important to note that the color change from pink to white when CCA bleaches can also alter larvae settlement due to a resulting lack of an appropriate spectral cue. In an experiment examining synthetic surfaces of either white or red hues, the coral larvae preferred a red surface $85 \%$ more often when compared to a white synthetic surface when both were also exposed to a chemical cue (Foster and Gilmour, 2016). The larvae themselves exhibit spectral variance by producing fluorescent proteins that change in response to environmental conditions. Fluorescent proteins are present in both larval and adult corals. While their function is not fully understood, they appear to be altered when the animal is exposed to stressors (Palmer et al., 2009). There is a demonstrated change in the expression of green fluorescent protein (GFP) in response to increased light, as well as red fluorescent protein (RFP) in response to heat(Rodriguez-Lanetty et al., 2009; Kenkel et al., 2011). The combined effect of increased water temperature and light intensity can also affect larval settlement, with a $16 \%$ decrease in larval settlement when they are exposed to both high temperatures and higher than normal light conditions (Kenkel et al., 2011).

When considering larval survival and physiology under increased temperatures, the symbiotic relationship between the animal and algal symbionts must be considered. Aposymbiotic larvae and symbiotic larvae both respond to stress in different ways, yet survivorship between temperatures of $28-32^{\circ} \mathrm{C}$ is not significantly different (Baird et al., 2006). When the aposymbiotic larvae from $A$. millepora were exposed to temperatures above their normal range for a period of $10 \mathrm{~h}$, heat shock protein gene expression was elevated but oxidative stress pathways remained unchanged (Rodriguez-Lanetty et al., 2009 ). The infection of symbionts within aposymbiotic larvae is a complex process that is just beginning to be understood under normal seawater temperatures, and may be altered under increased seawater temperatures (Weis et al., 2001). A study examining physiological responses to 4 clades of symbionts, as well as coral larvae infection, found that there were different optimum temperatures among the symbiont types where they had the ability to infect aposymbiotic coral larvae (Baird et al., 2008). Certain symbionts demonstrated lower rates of survival even at $32^{\circ} \mathrm{C}$, giving other symbiodinium strains a competitive edge. This advantage may come with tradeoffs however, as one of the most thermally tolerant strains had the slowest rate of population increase after infecting the coral larval host. This could have long-term impacts on the ability for the coral recruit to establish itself and grow, when fewer symbionts are available to provide nutrients needed for growth.

The means by which corals transmit their symbionts can affect stress in and survivorship of larvae. Hartmann et al. (2017) suggested that vertical transmission of zooxanthellae to coral eggs may exact a cost on gamete and larval survival due to the effect of increased buoyancy from lipids that result in the exposure to increased temperature and UV light at the sea surface. As many corals spawn during the rainy season in parts of the world, the sea surface can be a stressful environment with reduced salinity and increased toxicant concentrations from freshwater runoff. Hartmann et al. propose that the acquisition of symbionts after metamorphosis improves fertilization and out-crossing following spawning. The adaptive advantage of horizontal transmission of zooxanthellae is reflected in the fact that the majority of spawning corals (71\%) acquire their symbionts that way.

Under conditions of elevated temperature, algal symbionts can contribute to stress and mortality in coral larvae. Yakovleva et al. (2009) found coral planulae with zooxanthellae had higher mortality rates than those lacking algal symbionts at high temperatures. Mortality was attributed to oxidative damage tied to photosynthesis and was a function of both the magnitude of increased temperature and the duration of exposure. As with exposure to other physical and chemical stressors, zooxanthellae shift from being a mutualistic partner to becoming a burden at higher temperatures.

\section{Ocean Acidifcation}

Reduced oceanic $\mathrm{pH}$ attributed to increasing levels of atmospheric $\mathrm{CO}_{2}$ is a concern for the future of coral reefs as the structural foundation of these ecosystems results from the deposition of $\mathrm{CaCO}_{3}$ (aragonite). Chua et al. (2013), performed a study of the effects of $\mathrm{pH}$ on coral planulae using four relevant exposure treatments, and found no consistent effects on embryological development, larval survivorship and metamorphosis. They posit that larvae containing zooxanthellae may be more sensitive to the effects of decreased $\mathrm{pH}$ through metabolic effects on the symbionts. As coral planulae (generally) do not calcify while in the plankton, ocean acidification is more likely to directly affect larvae that do, such as those of sea urchins (Kurihara, 2008). However, the long-term effects of OA on coral recruitment and survivorship are expected to increase and, based on current predictions, be substantial. Reduced $\mathrm{pH}$ does affect the recruitment and growth of crustose coralline algae, which has been shown to be a preferred settlement substratum for many coral species (Kuffner et al., 2008). As small coral recruits can be outcompeted for space by a number of benthic organisms including algae, sponges and ascidians, reduced colony growth rates will affect survivorship as OA increases.

\section{SURVIVORSHIP-SELECTION/ADAPTATION VS. ACCLIMATIZATION}

Intraspecific variation, or inter-individual differences, in traits arise from genetic predispositions, past experiences and physiological states (Guest et al., 2012; Nanninga and Berumen, 2014), and is increasingly recognized as an important ecological factor that affects population dynamics and evolution of species, including reproductive success (Benton et al., 2006; Bolnick et al., 2011). In reef-building corals, significant differences in larval success has been observed among different genotypes (Meyer et al., 2009; Baums et al., 2013; Miller, 2014; Miller et al., 2016), as well as due to the parental experiences of exposure to stressful conditions (Putnam and Gates, 2015). This tells us 
that the larval stages are subject to strong selective pressures from their environmental conditions. Since persistence of populations, and ultimately species, depends on producing better adapted genotypes, the larval stages play a key role in coral population dynamics, connectivity, and survival. The fitness of existing individuals depends on their acclimatization potential, and many larval behaviors likely contribute to increasing their fitness; examples include selecting an optimal environment to settle (e.g., Davies et al., 2014; Dixson et al., 2014; Doropoulos et al., 2016), using reverse metamorphosis to escape from adverse conditions (Richmond, 1985; Negri et al., 2005), and potentially benefitting from increased size by forming a chimeric aggregate (Amar et al., 2008). When selective pressures exceed the acclimatization capacity of an individual, the individual will be eliminated from the population (i.e., selection). However, since no individual larva will experience exactly the same conditions, one evolutionary response is to produce genetically variable offspring so that the population will have enough adaptive capacity to respond to environmental heterogeneity and unpredictability. Intraspecific variation in reproductive success may, therefore, be a result of such an evolutionary strategy. Looking forward, corals and many other marine organisms will face strong selective forces from rising sea surface temperatures and ocean acidification (Webster et al., 2013; Baums et al., 2014). The larval stages known to be vulnerable to environmental stressors (Polato et al., 2010) will especially be subject to this strong selection, resulting in adaptation playing an essential role in how coral populations respond to changing environmental conditions. Standing genetic variation fuels such short-term adaptation (Stapley et al., 2010; Voolstra et al., 2011; Shinzato et al., 2012). In this regard, loss of genetic diversity already seen in some threatened coral populations (Baums et al., 2013) poses a great concern, as it reduces the coral's future reproductive and adaptive capacity. Human activities, including those responsible for global climate change, are predicted to reduce overall genetic

\section{REFERENCES}

Amar, K. O., Chadwick, N. E., and Rinkevich, B. (2008). Coral kin aggregations exhibit mixed allogeneic reactions and enhanced fitness during early ontogeny. BMC Evol. Biol. 8, 126-110. doi: 10.1186/1471-2148-8-126

Baird, A. H., Bhagooli, R., Nonaka, M., Yakovleva, I., Yamamoto, H. H., Hikada, M., et al. (2008). "Environmental controls on the establishment and development of algal symbiosis in corals," in Proceedings of the 11th International Coral Reef Symposium (Ft. Lauderdale, FL).

Baird, A. H., Gilmour, J., Kamiki, T., Nonaka, M., Pratchett, M., et al. (2006). "Temperature tolerance of symbiotic and nonsymbiotic coral larvae," in Proceedings of 10th International Coral Reef Symposium, (Okinawa), 38-42.

Bassim, K., and Sammarco, P. (2003). Effects of temperature and ammonium on larval development and survivorship in a scleractinian coral (Diploria strigosa). Marine Biol. 142, 241-252. doi: 10.1007/s00227-002-0953-Z

Baums, I. B., Devlin-Durante, M. K., and LaJeunesse, T. C. (2014). New insights into the dynamics between reef corals and their associated dinoflagellate endosymbionts from population genetic studies. Mol. Ecol. 23, 4203-4215. doi: $10.1111 / \mathrm{mec} .12788$

Baums, I. B., Devlin-Durante, M. K., Polato, N. R., Xu, D., Giri, S., Altman, N. S., et al. (2013). Genotypic variation influences reproductive success and thermal diversity in populations and species (Templeton et al., 2001; Pauls et al., 2013), which further threatens the persistence of coral reef ecosystems.

\section{SUMMARY AND CONCLUSIONS}

In a world of mounting anthropogenic stressors affecting the world's oceans and all life contained within, the ability of populations of organisms to survive, reproduce, evolve and grow is threatened at the local, regional and global levels. An understanding of the reproductive and recruitment behavior of marine organisms is essential to addressing the challenges of resource sustainability through responsive and effective management of the human activities responsible for resource declines. New tools such as genomics, proteomics and transcriptomics allow for the study of behaviors at the cellular and molecular levels, which when combined with more traditional studies of physiology and organismal behavior, have the potential to provide key guidance. The needs are pressing if there is to be a sound legacy of ocean resources for future generations.

\section{AUTHOR CONTRIBUTIONS}

RR organized the manuscript, coordinated sections with the coauthors, wrote several sections, provided figures and edited versions. KT wrote several sections and edited versions. NS wrote several sections, contributed figures and edited versions.

\section{FUNDING}

Funds partially supporting this research were provided by NOAA's Protected Resources Division, NOAA Fisheries' Pacific Islands Regional Office (NOAA grant \# NA17NMF4520144) and the National Fish and Wildlife Foundation (NFWF grant \# 34413).

stress tolerance in the reef building coral, Acropora palmata. Coral Reefs 32, 703-717. doi: 10.1007/s00338-013-1012-6

Benton, T. G., Plaistow, S. J., and Coulson, T. N. (2006). Complex population dynamics and complex causation: devils, details and demography. Proc. Biol. Sci. R. Soc. 273, 1173-1181. doi: 10.1098/rspb.2006.3495

Bolnick, D. I., Amarasekare, P., Araújo, M. S., Bürger, R., Levine, J. M., Novak, M., et al. (2011). Why intraspecific trait variation matters in community ecology. Trends Ecol. Evol. 26, 183-192. doi: 10.1016/j.tree.2011.0 1.009

Chua, C. M., Leggat, W., Moya, A., and Baird, A. H. (2013). Temperature affects the early life history stages of corals more than near future ocean acidification. Mar. Ecol. Progr. Ser. 475, 85-92 doi: 10.3354/meps 10077

Davies, S. W., Meyer, E., Guermond, S. M., and Matz, M. V. (2014). A cross-ocean comparison of responses to settlement cues in reef-building corals. PeerJ 2:e333. doi: $10.7717 /$ peerj.333

Diu, S. P. S. (2016). Trouble in Paradise: The Effects of Glyphosate and Roundup on Coral Fertilization and Settlement. Senior Thesis, Department of Ecology and Evolutionary Biology, Princeton University.

Dixson, D. L., Abrego, D., and Hay, M. E. (2014). Chemically mediated behavior of recruiting corals and fishes: a tipping point that may limit reef recovery. Science 345, 892-897. doi: 10.1126/science. 1255057 
Doropoulos, C., Roff, G., Y.-,Bozec, M., Zupan, M., Werminghausen, J., and Mumby, P. J. (2016). Characterising the ecological trade-offs throughout the early ontogeny of coral recruitment. Ecol. Monogr. 86, 20-44. doi: 10.1890/15-0668.1

Downs, C. A., Kramarsky-Winter, E., Segal, R., Fauth, J., Knutson, S., Bronstein, O., et al. (2016). Toxicopathological effects of the sunscreen UV Filter, Oxybenzone (Benzophenone-3), on Coral Planulae and Cultured Primary Cells and Its Environmental Contamination in Hawaii and the U.S. Virgin Islands. Arch. Environ. Contam. Toxicol. 70, 265-288. doi: 10.1007/s00244-015-0 $227-7$

Edmunds, P., Gates, R., and Gleason, D. (2001). The biology of larvae from the reef coral Porites astreoides, and their response to temperature disturbances. Mar. Biol. 139, 981-989. doi: 10.1007/s002270100634

Epstein, N., Bak. R. P. M., and Rinkevich, B. (2000). Toxicity of third generation dispersants and dispersed Egyptian crude oil on Red Sea Coral Larvae. Mar. Pollut. Bull. 40, 497-503. doi: 10.1016/S0025-326X(99)00232-5

Farina, O., Ramos, R., Bastidas, C., and García, E. (2008). Biochemical responses of cnidarian larvae to Mercury and Benzo(a)pyrene Exposure. Bull. Environ. Contam. Toxicol. 81, 553-557. doi: 10.1007/s00128-008-9534-2

Figueiredo, J., Baird, A. H., and Connolly, S. R. (2013). Synthesizing larval competence dynamics and reef-scale retention reveals a high potential for self-recruitment in corals. Ecology 94, 650-659 doi: 10.1890/12-0767.1

Figueiredo, J., Baird, A. H., Harii, S., and Connolly, S. R. (2014). Increased local retention of reef coral larvae as a result of ocean warming. Nat. Climate Change 4, 498-502 doi: 10.1038/nclimate2210

Foster, T., and Gilmour, J. P. (2016). Seeing red: coral larvae are attracted to healthy looking reefs. Mar. Ecol. Progr. Ser. 559, 65-71. doi: 10.3354/meps11902

Freckelton, M. L., Nedved, B. T., and Hadfield, M. G. (2017). Induction of invertebrate larval settlement; different bacteria, different mechanisms? Sci. Reports 7:42557. doi: 10.1038/srep42557

Gascoigne, J., and Lipcius, M. R. (2004). Allee effects in marine systems. Mar. Ecol. Prog. Ser. 269, 49-59 doi: 10.3354/meps269049

Golbuu, Y., and Richmond, R. H. (2007). Substratum preferences in planula larvae of two species of scleractinian corals, Goniastrea retiformis and Stylaraea punctata. Mar. Biol. 152, 639-644. doi: 10.1007/s00227-007-0717-x

Goodbody-Gringley, G., Wetzel, D. L., Gillon, D., Pulster, E., Miller, A., and Ritchie, K. B. (2013). Toxicity of deepwater horizon source oil and the chemical dispersant, corexit $\AA$ 9500, to Coral Larvae. PLoS ONE 8:e45574. doi: 10.1371/journal.pone.0045574

Graham, E. M., Baird, A. H., Connolly, S. R., Sewell, M. A., and Willis, B. L. (2017). Uncoupling temperature-dependent mortality from lipid depletion for scleractinian coral larvae. Coral Reefs 36, 97-104. doi: 10.1007/s00338-016-1501-5

Guest, J. R., Baird, A. H., Maynard, J. A., Muttaqin, E., Edwards, A. J., Campbell, S. J., et al. (2012). Contrasting patterns of coral bleaching susceptibility in 2010 suggest an adaptive response to thermal stress. PLOS ONE 7:e33353. doi: 10.1371/journal.pone.0033353

Hadfield, M. G., and Paul, V. J. (2001). "Chapter 13: natural chemical cues for settlement and metamorphosis of marine-invertebrate larvae," in Marine Chemical Ecology, eds J. B. McClintock, and B. J. Baker (Boca Raton, FL: CRC Press LLC), 431-461.

Hartmann, A. C., Baird, A. H., Knowlton, N., and Huang, D. (2017). The paradox of environmental symbiont acquisition in obligate mutualisms. Curr. Biol. 27, 3711-3716. doi: 10.1016/j.cub.2017.10.036

Hata, T., Madin, J. S., Cumbo, V. R., Denny, M., Figueiredo, J., Harii, S., et al. (2017). Coral larvae are poor swimmers and require fine-scale reef structure to settle. Sci. Reports 7:2249 doi: 10.1038/s41598-017-02402-y

Heyward, A. J. (1988). "Inhibitory effects of copper and zinc sulphates on fertilization in corals," in Proceedings of the 6th Coral Reef Symposium Vol. 2 (Townsville, QLD), 299-303.

Heyward, A. J., and Negri, A. P. (2010). Plasticity of larval pre-competency in response to temperature: observations on multiple broadcast spawning coral species. Coral Reefs, 29, 631-636. doi: 10.1007/s00338-009-0578-5

Inoue, M. (2004). Coral skeletal tin and copper concentrations at Pohnpei, Micronesia: possible index for marine pollution by toxic anti-biofouling paints. Environ. Pollut. 129, 399-407. doi: 10.1016/j.envpol.2003.11.009

IPCC. (2007). Climate Change 2007 - Impacts, Adaptation and Vulnerability Contribution of Working Group II to the Fourth Assessment Report of the IPCC. (IPCC).
Jones, G. P., Milicich, M. J., Emslie, M. J., and Lunow, C. (1999). Self-recruitment in a coral reef fish population. Nature 402, 802-804 doi: 10.1038/45538

Jones, R. (2004). Testing the 'photoinhibition' model of coral bleaching using chemical inhibitors. Mar. Ecol. Prog. Ser. 284, 133-145. doi: $10.3354 /$ meps 284133

Jones, R. J. (2005). The ecotoxicological effects of Photosystem II herbicides on corals. Mar. Pollut. Bull. 51, 495-506. doi: 10.1016/j.marpolbul.2005.06.027

Jones, R. J., Muller, J., Haynes, D., and Schreiber, U. (2003). Effects of herbicides diuron and atrazine on corals of the Great Barrier Reef, Australia. Mar. Ecol. Prog. Ser. 251, 153-167. doi: 10.3354/meps 251153

Kenkel, C. D., Traylor, M. R., Wiedenmann, J., Salih, A., and Matz, M. V. (2011). Fluorescence of coral larvae predicts their settlement response to crustose coralline algae and reflects stress. Proc. R. Soc. B Biol. Sci. 278, 2691-2697. doi: 10.1098/rspb.2010.2344

Knutson, S., Downs, C. A., and Richmond, R. H. (2011). Concentrations of Irgarol in selected marinas of Oahu, Hawaii and effects on settlement of coral larval. Ecotoxicology 21, 1-8. doi: 10.1007/s10646-011-0752-8

Kuffner, I. B., Andersson, A. J., Jokiel, P. L., Rodgers, K. S., and Mackenzie, F. T. (2008). Decreased abundance of crustose coralline algae due to ocean acidification. Nat. Geosci. 1, 114-117. doi: 10.1038/ngeo100

Kurihara, H. (2008). Effects of $\mathrm{CO}_{2}$-driven ocean acidification on the early developmental stages of invertebrates. Mar. Ecol. Prog. Ser. 373, 275-284 doi: 10.3354/meps07802

Lane, A., and Harrison, P. L. (2000). "Effects of oil contaminants on survivorship of larvae of the scleractinian reef corals Acropora tenuis, Goniastrea aspera and Platygyra sinensis from the Great Barrier Reef," in Proceedings of the 9th International Coral Reef Symposium (Bali), 23-27.

Markey, K. L., Baird, A. H., Humphrey, C., and Negri, A. P. (2007). Insecticides and a fungicide affect multiple coral life stages. Mar. Ecol. Progr Ser. 330, 127-137. doi: $10.3354 /$ meps330127

Meyer, A., Davies, S., Wang, S., Willis, B. L., Abrego, D., Juenger, T. E., et al. (2009). Genetic variation in responses to a settlement cue and elevated temperature in the reef-building coral Acropora millepora. Mar. Ecol. Progr. Ser. 392, 81-92. doi: $10.3354 /$ meps08208

Miller, M. W. (2014). Post-settlement survivorship in two Caribbean broadcasting corals. Coral Reefs 33, 1041-1046. doi: 10.1007/s00338-014-1177-7

Miller, M. W., Williams, D. E., and Fisch, J. (2016). Genet-specific spawning patterns in Acropora palmata. Coral Reefs 35, 1393-1398. doi: 10.1007/s00338-016-1472-6

Morgan, K. M., Perry, C. T., Smithers, S. G., Johnson, J. A., and Daniell, J. J. (2016). Evidence of extensive reef development and high coral cover in nearshore environments: implications for understanding coral adaptation in turbid settings. Sci. Reports 6:29616. doi: 10.1038/srep29616

Nanninga, G. B., and Berumen, M. L. (2014). The role of individual variation in marine larval dispersal. Front. Mar. Sci. 1:71. doi: 10.3389/fmars.2014.00071

Negri, A., and Marshall, P. (2009). TBT contamination of remote marine environments: ship groundings and ice-breakers as sources of organotins in the Great Barrier Reef and Antarctica. J. Environ. Manag. 90, S31-S40. doi: 10.1016/j.jenvman.2008.06.009

Negri, A. P., and Heyward, A. J. (2000). Inhibition of Fertilization and Larval Metamorphosis of the Coral Acropora millepora (Ehrenberg, 1834) by Petroleum Products. Mar. Pollut. Bull. 41, 420-427. doi: 10.1016/S0025-326X(00)00139-9

Negri, A. P., and Hoogenboom, M. O. (2011). Water contamination reduces the tolerance of coral larvae to thermal stress. PLoS ONE 6:e19703. doi: 10.1371/journal.pone.0019703

Negri, A. P., Marshall, P. A., and Heyward, A. J. (2007). Differing effects of thermal stress on coral fertilization and early embryogenesis in four Indo Pacific species. Coral Reefs 26, 759-763. doi: 10.1007/s00338-007-0258-2

Negri, A. P., Smith, L. D., Webster, N. S., and Heyward, A. J. (2002). Understanding ship-grounding impacts on a coral reef: potential effects of anti-foulant paint contamination on coral recruitment. Mar. Pollut. Bull. 44, 111-117. doi: 10.1016/S0025-326X(01)00128-X

Negri, A., Vollhardt, C., Humphrey, C., Heyward, A., Jones, R., Eaglesham, G., et al. (2005). Effects of the herbicide diuron on the early life history stages of coral. Mar. Pollut. Bull. 51, 370-383. doi: 10.1016/j.marpolbul.2004.10.053

Owen, R., Knap, A., Toaspern, M., and Carbery, K. (2002). Inhibition of coral photosynthesis by the antifouling herbicide Irgarol 1051. Mar. Pollut. Bull. 44, 623-632. doi: 10.1016/S0025-326X(01)00303-4 
Palmer, C. V., Modi, C. K., and Mydlarz, L. D. (2009). Coral fluorescent proteins as antioxidants. PLoS ONE 4:e7298. doi: 10.1371/journal.pone.0007298

Pauls, S. U., Nowak, C., Bálint, M., and Pfenninger, M. (2013). The impact of global climate change on genetic diversity within populations and species. Mol. Ecol. 22, 925-946. doi: 10.1111/mec.12152

Peters, E. C., Gassman, N. J., Firman, J. C., Richmond, R. H., and Power, E. A. (1997). Ecotoxicology of tropical marine ecosystems. J. Environ. Toxicol. Chem. 16, 12-40. doi: 10.1002/etc.5620160103

Polato, N. R., Voolstra, C. R., Schnetzer, J., DeSalvo, M. K., Randall, C. J., Szmant, A. M., et al. (2010). Location-specific responses to thermal stress in larvae of the reef-building coral Montastraea faveolata. PLOS ONE 5:e11221. doi: 10.1371/journal.pone.0011221

Putnam, H. M., and Gates, R. D. (2015). Preconditioning in the reef-building coral Pocillopora damicornis and the potential for trans-generational acclimatization in coral larvae under future climate change conditions. J. Exp. Biol. 218, 2365-2372. doi: 10.1242/jeb.123018

Reichelt-Brushett, A. J., and Harrison, P. L. (1999). The effect of copper, zinc and cadmium on fertilization success of gametes from scleractinian reef corals. Mar. Pollut. Bull. 38, 182-187. doi: 10.1016/S0025-326X(98)00183-0

Reichelt-Brushett, A. J., and Harrison, P. L. (2000). The effect of copper on the settlement success of larvae from the Scleractinian coral Acropora tenuis. Mar. Pollut. Bull. 41, 385-391. doi: 10.1016/S0025-326X(00)00131-4

Reichelt-Brushett, A. J., and Harrison, P. L. (2005). The effect of selected trace metals on the fertilization success of several scleractinian coral species. Coral Reefs 24, 524-534. doi: 10.1007/s00338-005-0013-5

Richmond, R. H. (1985). Reversible metamorphosis in coral planula larvae. Mar. Ecol. Progress Ser. 22, 181-185. doi: 10.3354/meps022181

Richmond, R. H. (1987). Energetics, competency, and long distance dispersal of planula larvae of the coral Pocillopora damicornis. Mar. Biol. 93, 527-533 doi: $10.1007 / \mathrm{BF} 00392790$

Richmond, R. H. (1990). "The effects of the El Niño southern oscillation on the dispersal of corals and other marine organisms," in Some Ecological Consequences of the 1982/83 El Niño Event to Marine Life ed Glynn, P. W. (Amsterdam: Elsevier Oceanography Series, 52. Elsevier North Holland Press), 127-140.

Richmond, R. H. (1993). "Effects of coastal runoff on coral reproduction," in Proceedings of the Colloquium on Global Aspects of Coral Reefs: Health, Hazards, and History, ed R. N. Ginsburg (Miami, FL: Rosenstiel School of Marine and Atmospheric Science), 360-364.

Richmond, R. H. (2014). Making science matter - Forging effective partnerships for coral reef conservation. Limnol. Oceanogr. Bull. 23, 52-56. doi: 10.1002/lob.201423352

Richmond, R. H., and Jokiel, P. L. (1984). Lunar Periodicity in Larva Release in the Reef Coral Pocillopora damicornis at Enewetak and Hawaii. Bull. Mar. Sci. 34, 280-287.

Rodriguez-Lanetty, M., Harii, S., and Hoegh-Guldberg, O. (2009). Early moleculars responses of coral larvae to hyperthermal stress. Mo. Ecol. 18, 5101-5114. doi: 10.1111/j.1365-294X.2009.04419.x

Sammarco, P. W. (1982). Polyp Bail-Out: an escape response to environmental stress and a new means of reproduction in corals. Mar. Ecol. Progr. Ser. 198, 57-65. doi: 10.3354/meps010057

Sammarco, P. W., and, A.,Andrews, C. (1989). The Helix experiment: differential localized dispersal and recruitment patterns in Great Barrier Reef corals. Limnol. Oceanogr. 34, 896-912. doi: 10.4319/lo.1989.34.5.0896

Shinzato, C., Shoguchi, E., Kawashima, T., Hamada, M., Hisata, K., Tanaka, M., et al. (2012). Using the Acropora digitifera genome to understand coral responses to environmental change. Nature 476, 320-323. doi: $10.1038 /$ nature 10249

Sneed, J. M., Sharp, K. H., Ritchie, K. B., and Paul, V. J. (2014). The chemical cue tetrabromopyrrole from a biofilm bacterium induces settlement of multiple Caribbean corals. Proc. R. Soc. B 281:20133086. doi: 10.1098/rspb.2013.3086

Stapley, J., Reger, J., Feulner, P. G., Smadja, C., Galindo, J., Ekblom, R., et al. (2010). Adaptation genomics: the next generation. Trends Ecol. Evol. 25, 705-712. doi: $10.1016 /$ j.tree.2010.09.002

Tebben, J., Motti, C. A., Siboni, N., Tapiolas, D. M., Negri, A. P., Schupp, P. J., et al. (2015). Chemical mediation of coral larval settlement by crustose coralline algae. Sci. Reports 5:10803. doi: 10.1038/srep10803

Tebben, J., Tapiolas, D. M., Motti, C. A., Abrego, D., Negri, A. P., Blackall, L. L., et al. (2011). Induction of larval metamorphosis of the coral Acropora millepora by tetrabromopyrrole isolated from a Pseudoalteromonas Bacterium. PLoS ONE 6:e19082. doi: 10.1371/journal.pone.0019082

Templeton, A. R., Robertson, R. J., Brisson, J., and Strasburg, J. (2001). Disrupting evolutionary processes: the effect of habitat fragmentation on collared lizards in the Missouri Ozarks. Proc. Natl. Acad. Sci. U.S.A. 98, 5426-5432. doi: 10.1073/pnas.091093098

van Dam, J. W., Negri, A. P., Uthicke, S., and Mueller, J. F. (2011). "Chemical pollution on coral reefs: exposure and ecological effects," in Ecological Impacts of Toxic Chemicals, eds F. Sánchez-Bayo, P. J. van den Brink, and R. M. Mann (Bentham Science Publishers Ltd.), 187-211.

Vermeij, M. J., Marhaver, K. L., Huijbers, C. M., Nagelkerken, I., and Simpson, S. D. (2010). Coral larvae move toward reef sounds. PLoS ONE 5:e10660. doi: 10.1371/journal.pone.0010660

Vermeij, M. J., Smith, J. E., Smith, C. M., Vega Thurber, R., and Sandin, S. A. (2008). Survival and settlement success of coral planulae: independent and synergistic effects of macroalgae and microbes. Oecologia 159, 325-336. doi: 10.1007/s00442-008-1223-7

Victor, S., Neth, L., Golbuu, Y., Wolanski, E., and Richmond, R. (2006). Sedimentation in mangroves and coral reefs in a wet tropical Island, Pohnpei, Micronesia. Estuar. Coast. Shelf Sci. 66, 409-416. doi: 10.1016/j.ecss.2005.07.025

Victor, S., and Richmond, R. H. (2005). Effect of copper on fertilization success in the reef coral Acropora surculosa. Mar. Pollut. Bull. 50, 1448-1451. doi: 10.1016/j.marpolbul.2005.09.004

Vijayavel, K., Downs, C. A., Ostrander, G. K., and Richmond, R. H. (2012). Oxidative DNA damage induced by iron chloride in the larvae of the lace coral Pocillopora damicornis. Comp. Biochem. Physiol. C 155, 275-280. doi: 10.1016/j.cbpc.2011.09.007

Voolstra, C. R., Sunagawa, S., Matz, M. V., Bayer, T., Aranda, M., Buschiazzo, E. et al. (2011). Rapid evolution of coral proteins responsible for interaction with the environment. PLoS ONE 6:e20392. doi: 10.1371/journal.pone.0020392

Webster, N. S., Soo, R., Cobb, R., and Negri, A. P. (2010). Elevated seawater temperature causes a microbial shift on crustose coralline algae with implications for the recruitment of coral larvae. ISME J. 5, 759-770. doi: 10.1038/ismej.2010.152

Webster, N. S., Uthicke, S., Bott,é, E. S., Flores, F., and Negri, A. P. (2013). Ocean acidification reduces induction of coral settlement by crustose coralline algae. Global Change Biol. 19, 303-315. doi: 10.1111/gcb.12008

Weis, V., Reynolds, W., deBoer, M., and Krupp, D. (2001). Host-symbiont specificity during onset of symbiosis between the dinoflagellates Symbiodinium spp. and planula larvae of the scleractinian coral Fungia scutaria. Coral Reefs 20, 301-308. doi: 10.1007/s003380100179

Wolanski, E., Richmond, R., McCook, L., and Sweatman, H. (2003). Mud, marine snow and coral reefs. Am. Sci. 91, 44-51. doi: 10.1511/2003.1.44

Woods, R. M., Baird, A. H., Mizerek, T. L., and Madin, J. S. (2016). Environmental factors limiting fertilisation and larval success in corals. Coral Reefs 35, 1433-1440 doi: 10.1007/s00338-016-1494-0

Woolsey, E. S., Keith, S. A., Byrne, M., Schmidt-Roach, S., and Baird, A. H. (2015). Latitudinal variation in thermal tolerance thresholds of early life stages of corals. Coral Reefs 34, 471-478 doi: 10.1007/s00338-0141253-z

Yakovleva, I. M., Baird, A. H., Yamamoto, H. H., Bhagooli, R., Nonaka, M., and Hidaka, M. (2009). Algal symbionts increase oxidative damage and death in coral larvae at high temperatures. Mar. Ecol. Progr. Ser. 378, 105-112 doi: $10.3354 /$ meps07857

Conflict of Interest Statement: The authors declare that the research was conducted in the absence of any commercial or financial relationships that could be construed as a potential conflict of interest.

The reviewer $\mathrm{AB}$ and handling Editor declared their shared affiliation.

Copyright (c) 2018 Richmond, Tisthammer and Spies. This is an open-access article distributed under the terms of the Creative Commons Attribution License (CC BY). The use, distribution or reproduction in other forums is permitted, provided the original author(s) and the copyright owner(s) are credited and that the original publication in this journal is cited, in accordance with accepted academic practice. No use, distribution or reproduction is permitted which does not comply with these terms. 